\title{
Direct seeding of 16 Brazilian savanna trees: responses to seed burial, mulching and an invasive grass
}

\author{
Raíssa R.P. Silva \& Daniel L.M. Vieira iD
}

Keywords

Cerrado; Ecological restoration; Functional traits; Neotropical savanna; Restoration ecology; Seed traits; Seedling morphofunctional types

\section{Abbreviations \\ $\mathrm{CHR}=$ cryptocotylar hypogeal with reserve storage cotyledons; PEF = phanerocotylar epigeal with foliaceous cotyledons; PER = phanerocotylar epigeal with reserve storage cotyledons; PHR = phanerocotylar hypogeal with reserve storage cotyledons. \\ Nomenclature \\ Flora do Brasil 2020 in construction. Jardim Botânico do Rio de Janeiro. (http://floradobra sil.jbrj.gov.br) \\ Received 22 July 2016 \\ Accepted 3 February 2017 \\ Co-ordinating Editor: Alicia Teresa Rosario Acosta}

Silva, R.R.P. (raissa.rpsilva@gmail.com) ${ }^{1}$, Vieira, D.L.M. (corresponding author, daniel.vieira@embrapa.br)²

${ }^{1}$ Pós Graduação em Ciências Florestais, Universidade de Brasília, Campus Universitário Darcy Ribeiro, Asa Norte, 70910-900, Brasília, DF, Brazil;

${ }^{2}$ Embrapa Recursos Genéticos e Biotecnologia, Asa Norte, Caixa Postal 02372, 70770-900,

Brasília, DF, Brazil

\begin{abstract}
Aims: To address whether seed and seedling functional traits have a significant effect on germination rates and seedling survival in direct-seeding restoration efforts. We tested the hypotheses that: (1) seed burial only favours the emergence of round seeds; and (2) straw mulching improves soil moisture and prevents the emergence of the invasive grass Urochloa decumbens, promoting the establishment of native tree seedlings.
\end{abstract}

Location: Experimental field, Central Brazil. Savanna, recently dominated by exotic pasture.

Methods: We evaluated the effects of seed burial (surface and buried) and mulching (no-mulch, $5-\mathrm{cm}$ straw mulch and $10-\mathrm{cm}$ straw mulch) on the emergence, survival and growth of 16 species of native Cerrado tree species with variable seed sizes and shapes and seedling types. Thirty seeds of each species were sown per treatment combination in three blocks.

Results: Seed burial did not affect the emergence of species with round seeds, but negatively affected species with flat seeds and phanerocotylar-epigealfoliaceous seedlings. Straw mulching reduced the emergence of flat seeds and phanerocotylar seedlings, but increased soil moisture and strongly reduced $U$. decumbens emergence, resulting in a higher growth rate of tree seedlings up to $1 \mathrm{yr}$ for five species.

Conclusion: Direct seeding is an effective technique to plant a mixture of Cerrado tree species for restoration, provided the soil is well prepared and there are mechanisms to control invasive species.

\section{Introduction}

The first record of direct tree seeding dates back to 1870 in Australia (Fergus 2004; Carr et al. 2009), but as recently as $20 \mathrm{yr}$ ago this technique had been formally evaluated in only a few dozen scientific studies. Direct seeding is seen as an alternative strategy for the restoration of forest and savanna ecosystems, because the costs are lower and it is easier to implement than planting nursery-grown seedlings (Cole et al. 2011; Campos-Filho et al. 2013; Palma \& Laurance 2015). In addition, this approach has ecological advantages. For instance, directly seeded trees are likely to establish in suitable microsites because seeds are planted in large quantities and the initial seed and seedling densities are closer to those of early secondary succession areas (Sovu et al. 2010; Schneemann \& McElhinny 2012; Campos-Filho et al. 2013), recreating competitive and facilitative interactions.

When adopting or developing direct seeding methods for restoration programmes, seed and seedling functional traits must be taken into account, because it is possible that no one method will be adequate for all species in a 
community (Jiménez-Alfaro et al. 2016). For instance, large seeds have more reserves, which increases seed and seedling tolerance to unfavourable conditions such as herbivory and low availability of light, water and nutrients, and results in larger and more vigorous seedlings compared to small seed species (Camargo et al. 2002; Baraloto \& Forget 2007; Garcia-Orth \& Martinez-Ramos 2008). Seed shape has a similar influence on the outcome of germination: round seeds penetrate the soil more easily and persist for longer periods in the seed bank before germinating, while flat seeds tend to remain on the soil surface and germinate faster due to a thinner seed coat, which facilitates imbibition (Moles et al. 2000; Tunjai \& Elliott 2012). Due to the ephemeral nature of cotyledons, it is not easy to determine the functional morphology of seedlings, but morphological seed traits are correlated to seedling traits. Larger seeds tend to have hypogeal reserve cotyledons, while smaller seeds tend to produce seedlings with epigeal leaf-like cotyledons (Ibarra-Manriquez et al. 2001; Ressel et al. 2004; Baraloto \& Forget 2007). These traits may in turn affect post-germination success. For instance, seedlings with epigeal foliaceous cotyledons may be less likely to grow through the soil or litter layer during emergence than hypogeal seedlings.

Beyond the functional traits of seeds and seedlings, abiotic and biotic constraints must also be considered when developing a direct seeding programme. Among the obstacles faced by seeds and seedlings in degraded areas of the seasonal tropics, some of the most relevant are exposure to high temperatures, low humidity, predation and competition with invasive alien species (Woods \& Elliott 2004; Vieira \& Scariot 2006; Doust et al. 2008; Sovu et al. 2010). In the Brazilian savannas (i.e. Cerrado sensu stricto) tree seedling establishment and growth are constrained by frequent fires and high precipitation seasonality, with up to 5 months of drought (Furley 1999; Hoffmann 2000). Seedling survival increases with protection from fire (Moreira 2000), but these seedlings still experience high irradiance and water deficit (Salazar et al. 2012a). In addition, restoration of savannas on previously cultivated pastures and crop fields is hindered by the high density of invasive exotic grasses (Martins et al. 2011). In the Cerrado, competition between grasses and tree seedlings is amplified by water deficit during the dry season, which suggests that most competition takes place below-ground, for water and nutrients (Pereira et al. 2013). Today, exotic pastures occupy $29 \%$ of the range of this biome, represent $65 \%$ of the converted land (Ministério do Meio Ambiente, Brasil 2015) and are the main land-use type targeted by restoration programmes.

A few relatively simple techniques may be used to address challenges to the success of direct seeding. Seed burial, for instance, hides seeds from predators and reduces seed desiccation caused by high temperatures at the soil surface (Garcia-Orth \& Martinez-Ramos 2008; Sovu et al. 2010; Guarino and Scariot 2014). Seed and seedling desiccation may also be prevented by covering the soil with mulch, such as mowed grass (Doust et al. 2006). Mulching also increases soil moisture, reduces soil erosion (Haywood 1999) and acts as a barrier to the germination of weeds, which have small seeds and are generally positively photoblastic (Martins et al. 2011). Nevertheless, more research is needed to address which species and sets of functional traits, as well as seeding techniques, might increase the success of direct seeding. This would result in the inclusion of a more diverse set of species in direct seeding programmes, which would no longer act as a biodiversity filter in restoration programmes.

This study provides a community-level analysis of emergence, establishment and growth of 16 native Cerrado tree species, encompassing a wide range of seed traits (Palma $\delta$ Laurance 2015). We tested the use of seed burial (surface and buried) and mulching (no-mulch, 5-cm and $10-\mathrm{cm}$ mulch) as possible improvements to the direct seeding method. We hypothesized that seed burial and mulching would increase moisture and reduce the temperature extremes seeds are exposed to, but impose a physical barrier to seedling emergence, especially for small, flat seeds. Concurrently with tree seeding, we sowed Urochloa decumbens (synonym Brachiaria decumbens), one of the most widespread exotic pasture grasses in Cerrado, in all plots. This allowed us to test a second hypothesis, that mulching improves tree seedling survival and growth by reducing the emergence of $U$. decumbens and lowering competition for seedlings.

\section{Methods}

\section{Study area}

The experiment was conducted at an experimental field of the University of Brasilia, in the Federal District, Brazil ( $15^{\circ} 56^{\prime} \mathrm{S}, 47^{\circ} 56^{\prime} \mathrm{W}, 1080 \mathrm{~m}$ a.s.l.). Average annual rainfall is $1336 \mathrm{~mm}$, and $87 \%$ of the precipitation is concentrated from Oct to Mar. Average annual temperature is $20{ }^{\circ} \mathrm{C}$, the hottest month is Oct $\left(22^{\circ} \mathrm{C}\right)$ and the coldest is Jul $\left(17^{\circ} \mathrm{C}\right.$; http://www.fal.unb.br). The predominant soil is a dark red Latosol (Oxisol), which has high aluminium and low calcium and magnesium content (Libano \& Felfili 2006). Cerrado (Brazilian savanna) fragments near the experimental area have 1147 trees $\cdot \mathrm{ha}^{-1}$ and basal area of $9.2 \mathrm{~m}^{2} \cdot \mathrm{ha}^{-1}$; trees are $3-5-\mathrm{m}$ tall, and some reach $12 \mathrm{~m}$ (Felfili \& Silva Júnior 1988). The most abundant tree species are Qualea parviflora Mart., Ouratea hexasperma (A. St.-Hil.) Tiegh., Qualea grandiflora Mart., Acinodendron pohlianum (Cogn.) Kuntze, Caryocar brasiliense A.St.-Hil., Tachigali vulgaris L.G.Silva \& H.C.Lima, Schefflera macrocarpa 
(Cham. \& Schltdl.) Frodin, Vochysia thyrsoidea Pohl, Dalbergia miscolobium Benth. and Kielmeyera coriacea Mart. \& Zucc. (Almeida et al. 2014).

\section{Studied species}

Initially, we selected 18 native Cerrado species that had seeds available during the collection period (Jul-Nov 2011). However, two species were excluded from the analyses because they did not germinate in any treatment (Dimorphandra mollis Benth. and S. macrocarpa (Cham. \& Schltdl.) Frodin). Species were classified according to seed shape and the morpho-functional traits of the seedlings (Table 1). All the species studied were listed among the 100 most frequent trees in at least one of the six Cerrado floristic provinces (Bridgewater et al. 2004). In addition, the seed traits of these species represented the full range described for several tree assemblages around the world (reviewed by Ceccon et al. 2016). Seeds were removed from fruits, unless they were winged; wings protect seeds from desiccation without constraining germination (D.L.M. Vieira, pers. obs.). We did not break seed dormancy to preserve resistance to dry spells. Although the germination of some seeds may be accelerated through scarification to break dormancy, all studied species started to germinate in the first month after the onset of the rains. Non-scarified seed lots were germinated in the laboratory to assess germinability.

\section{Experimental design}

We used a factorial block design, crossing the factors seed burial (surface and 3-5-cm deep) and straw mulching (nomulch, $5-\mathrm{cm}$ mulch and $10-\mathrm{cm}$ mulch) for a total of six treatment combinations. The exotic grass planted along with tree seeds, $U$. decumbens (Stapf) R.D.Webster, is a 50$\mathrm{cm}$ tall semi-stoloniferous African perennial grass, with stoloniferous and caespitose growth, that has been widely introduced and cultivated in Neotropical savannas to increase pasture productivity (Guenni et al. 2002).

The experimental site had been cultivated with the exotic grasses $U$. decumbens and Melinis minutiflora P. Beauv. before the experiment was established. The area was mowed and ploughed, and in each block, three 36.0 $\mathrm{m} \times 1.2 \mathrm{~m}$ beds were established $70 \mathrm{~cm}$ apart using a rotary hoe bed former, allowing us to sow seeds and survey seedlings without stepping on the beds. Beds were flat and had no lumps; they were divided into three $12.0 \mathrm{~m} \times 1.2 \mathrm{~m}$ strips for the application of each straw mulch treatment, and each strip was divided into two $6.0 \mathrm{~m} \times 1.2 \mathrm{~m}$ plots for the seed burial treatments. Thirty seeds of 16 species were sown per treatment combination in each block ( 30 seeds $\times 6$ treatments $\times 3$ blocks $=540$ seeds of each species; Appendix S1). Blocks were positioned along a gentle slope, $5 \mathrm{~m}$ apart from each other. Seeds from each species were sown in rows $20 \mathrm{~cm}$ apart from each other; seeds were sown every $20 \mathrm{~cm}$ along each row. For seed burial, holes were created with a wooden

Table 1. Tree species from the Cerrado biome included in a direct seeding experiment in Brasília, Distrito Federal, central Brazil.

\begin{tabular}{|c|c|c|c|c|}
\hline Species & Seedling Type & Seed Shape & Dry Mass $\pm S D(g)^{b}$ & $\begin{array}{l}\text { Laboratory } \\
\text { Emergence (\%) }\end{array}$ \\
\hline Anacardium occidentale L. & $\mathrm{CHR}^{\mathrm{b}}$ & Round & $1.66 \pm 0.33$ & 50 \\
\hline Anadenanthera colubrina (Vell.) Brenan. & $\mathrm{PHR}^{\mathrm{a}}$ & Flat & $0.06 \pm 0.06$ & 77 \\
\hline Aspidosperma macrocarpon Mart. & $\mathrm{PHR}^{d}$ & Flat & $0.70 \pm 0.06$ & 46 \\
\hline Brosimum gaudichaudii Trécul & $\mathrm{CHR}^{\mathrm{a}}$ & Round & $1.23 \pm 0.25$ & ND \\
\hline Copaifera langsdorffii Desf. & $\mathrm{PER}^{\mathrm{a}}$ & Round & $0.35 \pm 0.05$ & 66 \\
\hline Dalbergia miscolobium Benth. & $\mathrm{PER}^{\mathrm{c}}$ & Flat & $0.07 \pm 0.01$ & 90 \\
\hline Dipteryx alata Vogel & $\mathrm{PHR}^{\mathrm{a}}$ & Round & $0.92 \pm 0.15$ & ND \\
\hline Enterolobium gummiferum (Mart.) J.F.Macbr. & $\mathrm{PER}^{\mathrm{a}}$ & Round & $0.41 \pm 0.04$ & 78 \\
\hline Eriotheca pubescens (Mart. \& Zucc.) Schott \& Endl. & $\mathrm{PHR}^{\mathrm{a}}$ & Round & $0.02 \pm 0.02$ & $0^{\mathrm{e}}$ \\
\hline Eugenia dysenterica (Mart.) DC. & $\mathrm{CHR}^{\mathrm{b}}$ & Round & $0.43 \pm 0.07$ & 59 \\
\hline Hymenaea stigonocarpa Mart. ex Hayne & $\mathrm{PER}^{\mathrm{c}}$ & Round & $3.31 \pm 0.46$ & 70 \\
\hline Kielmeyera coriacea Mart. \& Zucc. & $\mathrm{PEF}^{\mathrm{a}}$ & Flat & $0.07 \pm 0.04$ & 74 \\
\hline Magonia pubescens A.St.-Hil. & $\mathrm{PHR}^{\mathrm{C}}$ & Flat & $1.76 \pm 0.09$ & 95 \\
\hline Qualea grandiflora Mart. & $\mathrm{PEF}^{\mathrm{a}}$ & Flat & $0.13 \pm 0.02$ & 74 \\
\hline Solanum lycocarpum A.St.-Hil. & $\mathrm{PEF}^{\mathrm{b}}$ & Flat & $0.02 \pm 0.02$ & 26 \\
\hline Tabebuia aurea (Silva Manso) Benth. \& Hook. f. ex S. Moore & $\mathrm{PEF}^{\mathrm{C}}$ & Flat & $0.13 \pm 0.01$ & 91 \\
\hline
\end{tabular}

Morpho-functional traits of the seedlings: CHR, cryptocotylar hypogeal with reserve storage cotyledons; PEF, phanerocotylar epigeal with foliaceous cotyledons; PER, phanerocotylar epigeal with reserve storage cotyledons; PHR, phanerocotylar hypogeal with reserve storage cotyledons. Seed shape: flat, seeds with a flat surface; round $=$ round or oval-shaped seeds (visually determined). Dry weight of seeds in grams with SD.

Adapted from: ${ }^{\mathrm{a}}$ Ressel et al. (2004); b based on four replications of 25 seeds (D.A. Silva, seed physiologist at Embrapa Genetic Resources \& Biotechnology,

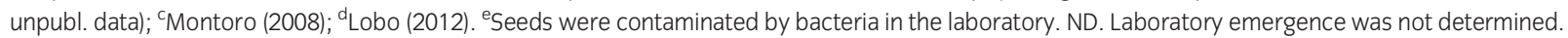


stick, and the soil was levelled after sowing. In all treatments, $U$. decumbens was seeded manually at the usual density for pasture formation (ca. $0.3 \mathrm{seed} \cdot \mathrm{cm}^{-2}$ ) before the mulch was applied. The mulch consisted of $U$. decumbens, which was moved from the surrounding areas, dried naturally in the field and manually placed on the ground. The experiment was established in Nov 2011 , at the beginning of the rainy season.

\section{Data collection}

Environmental variables were only compared between mulch treatments, since seed burial does not affect environmental variables or $U$. decumbens emergence. To estimate soil moisture (\%), soil samples were collected from each mulch cover treatment (no-mulch, 5-cm and $10-\mathrm{cm}$ mulch) at the surface and at a depth of $50 \mathrm{~cm}$ in Jul (nine samples per treatment per cover), Oct (18 samples) and Nov (seven samples) of 2012. Samples were weighed before and after being dried at $105^{\circ} \mathrm{C}$ to a constant weight in a kiln (gravimetric method, using a $0.01 \mathrm{~g}$ precision balance). To estimate photosynthetic photon flux density (PPFD) at $10 \mathrm{~cm}$ above the surface (the height of most of the seedlings in the experiment), 14 light measurements per treatment and one measurement at full sun were taken. The final measurement was calculated as (PPFD at treatment/PPFD at full sunlight) $\times 100$. These measurements were taken in Jul 2012 using a quantum sensor (LI-190; LI-Cor, Lincoln, NB, US). The number of $U$. decumbens tussocks in 18 randomly distributed $25 \mathrm{~cm} \times 25 \mathrm{~cm}$ plots per treatment were counted to assess the emergence of this grass. This census was carried out in Jul 2012, at the same time soil moisture and PPFD were measured.

We carried out monthly surveys of emergence and survival of seedlings over 16 months (including two rainy seasons). Emergence was logged when seedlings emerged through the mulch, or through the soil for the no-mulch treatment. Seedlings were then identified by a numbered tag to monitor their survival. Height and diameter at soil level of all surviving plants were measured after 16 months.

\section{Data analyses}

We used ANOVAs to compare the effects of mulching on soil moisture, PPFD and U. decumbens emergence, with blocks as a random variable without interaction. We tested if different seed sizes, seed shapes and seedling types interacted with the seed burial and mulching treatments using factorial ANOVAs, nesting species into seed size (small: <0.1 g; medium: 0.1-1.0 g; large: $>1.0 \mathrm{~g}$ ), seed shape (flat, round) or seedling type (CHR, PEF, PER, PHR) and treating blocks as a random variable without interaction. Assuming that species are differently affected by treatments, we used one factorial ANOVA for each species to compare the effects of seed burial, mulching and their interaction on the emergence of tree species, with blocks as a random variable without interaction. In the case of seedling survival (number of live seedlings at 16 months per number of seedlings that emerged) and seedling size $($ volume $=$ height $/ 3 \times$ basal area, assuming that seedlings have a conical shape), only the effect of mulching was tested, because there was no reason to examine the effect of planting depth after the seedlings had emerged. Seedling emergence did not deviate significantly from the normal distribution and was not heteroscedastic, except for one species (verified by a Bartlett test). Seedling survival did not deviate significantly from the normal distribution and was not heteroscedastic, except for two species. Shoot size at 16 months was $\log$ 10-transformed to achieve normal distribution. After transformation five species did not meet homoscedasticity. For all species, the ratio of largest to smallest variance was always $<2$. One bed was not sown with $H$. stignocarpa, and the value was replaced with the average of the other two beds. Tukey HSD tests were used for all post-hoc comparisons.

\section{Results}

\section{Environmental variables}

In Jul (mid-dry season), soil moisture at the surface was higher under $10 \mathrm{~cm}$ of mulch $(11.2 \pm 0.9 \%, \pm \mathrm{SE})$ than in the $5-\mathrm{cm}$ mulch $(8.0 \pm 0.7 \%)$ and no-mulch treatments $\left(6.6 \pm 0.6 \% ; F_{2,46}=13.3, P<0.001\right)$, and soil moisture was also higher at $50-\mathrm{cm}$ depth for $10-\mathrm{cm}$ mulch $(18.6 \pm 0.4 \%)$ than no-mulch $\left(17.1 \pm 0.4 \% ; F_{2,46}=6.0\right.$, $P=0.008)$. In Oct (early rainy season), soil moisture at the surface increased with increasing mulch cover (no-mulch, $8.5 \pm 0.5 \%$; 5 -cm mulch, $11.7 \pm 0.4 \% ; 10-\mathrm{cm}$ mulch, $\left.14.9 \pm 0.6 \% ; F_{2,98}=40.8, P<0.001\right)$, but there were no significant differences at $50-\mathrm{cm}$ depth $(18.0 \%$ across treatments; $F_{2,98}=3.0, P=0.060$ ). In Nov (rainy season) there were no significant differences in soil moisture at the surface $\left(19.9 \%\right.$ across treatments; $\left.F_{2,33}=2.3, P=0.130\right)$ or 50-cm depth $\left(22.6 \%\right.$ across treatments; $F_{2,33}=0.3$, $P=0.774 ;$ Appendix S2). Mulch strongly inhibited the emergence of $U$. decumbens, which was 12 times higher in the no-mulch treatment compared to the $10-\mathrm{cm}$ mulch (Appendix S2). As a result, the canopy formed by $U$. decumbens allowed only $47 \pm 8 \%$ of the light to reach the seedling stratum in the no-mulch treatment, compared to $60 \pm 7 \%$ in $5-\mathrm{cm}$ mulch and $81 \pm 6 \%$ in the $10-\mathrm{cm}$ mulch $\left(F_{2,35}=5.2, P=0.011\right.$; Appendix S2). 


\section{Seedling emergence by functional traits}

Mulching did not affect the emergence of flat and round seeds differently (Fig. la), but flat seeds on the surface had higher emergence $(56 \pm 3 \%)$ than those that were buried ( $26 \pm 3 \%$; Fig. $2 \mathrm{~b}$ ). In contrast, the emergence of round seeds on the surface $(42 \pm 3 \%)$ did not differ from the emergence of buried round seeds (48 $\pm 3 \%$; Fig. 1b). Phanerocotylar epigeal with foliaceous cotyledons (PEF) seedlings also had better emergence when sown on the surface $(54 \pm 4 \%)$ than when buried $(21 \pm 5 \%)$, but there were no differences in emergence between surface-sown and buried seeds of the other seedling types (Fig. 1c). Emergence did not differ among mulching treatments for any of the seedling types (Fig. ld). Small, medium and large seeds were not affected differently by the mulching and burial treatments (Fig. 1e, f, Appendix S3).

\section{Seedling emergence by species}

Seven out of the eight flat-seeded species had lower seedling emergence when buried. Similarly, the 10-cm mulch treatment reduced the emergence of five flat-seeded species. For flat-seeded species, a 3-cm soil layer greatly reduced emergence, even in the no-mulch treatment. In the case of unburied flat seeds, mulch cover gradually reduced emergence, resulting in a significant interaction between seed burial and mulch cover for three flat-seeded species. In contrast, seedling emergence of round-seeded species did not differ between buried and surface seeding treatments, except for Eugenia dysenterica, which has (a)

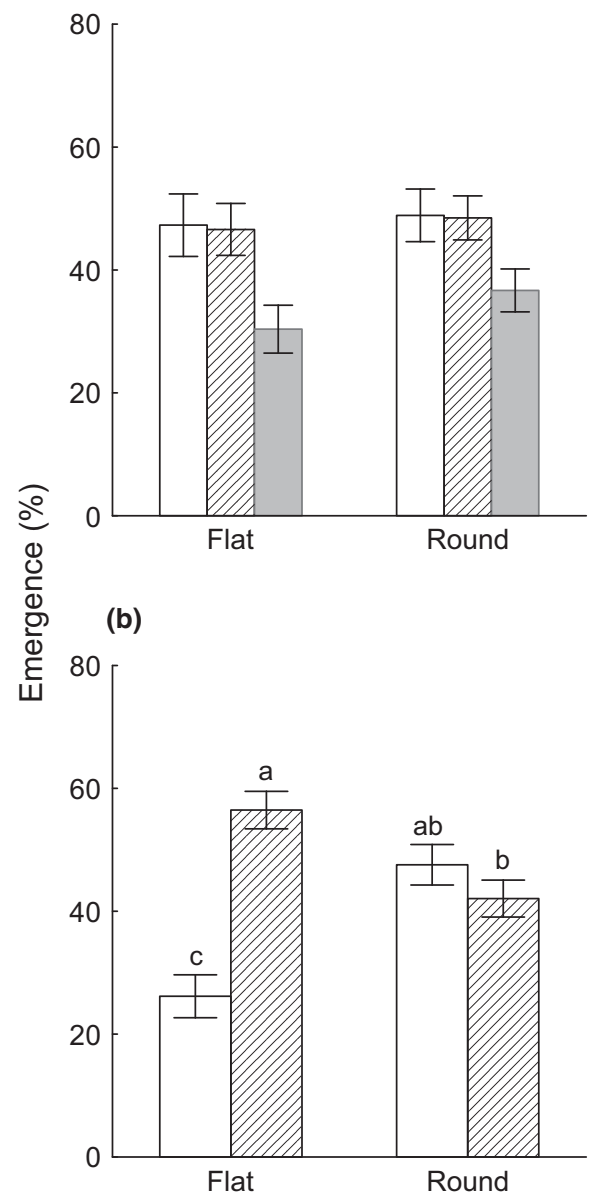

(c) $\quad \square 0 \mathrm{~cm} \oslash 5 \mathrm{~cm} \square 10 \mathrm{~cm}$

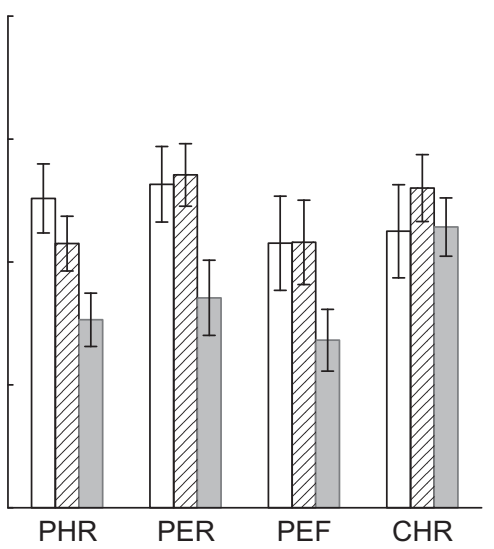

(d)

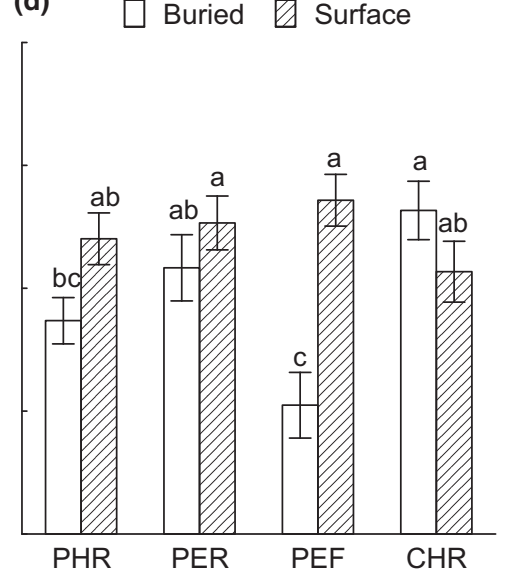

(e)

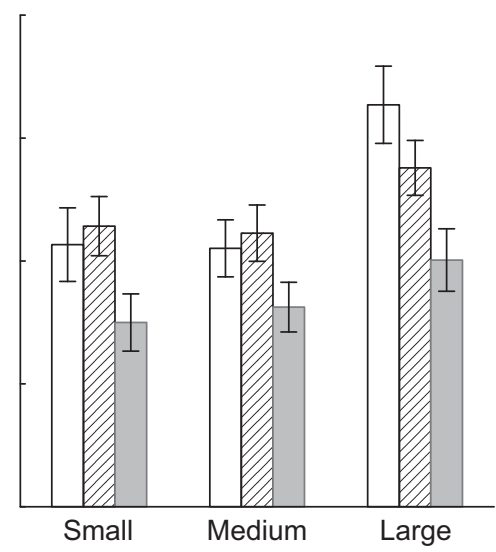

(f)

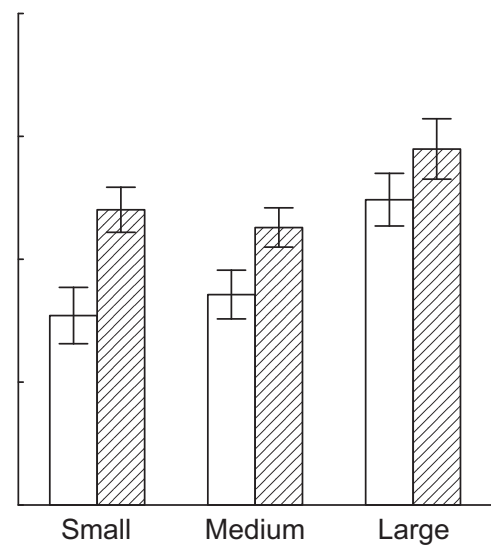

Fig. 1. Emergence (\%) of Cerrado tree species with round or flat seeds and CHR, PEF, PER or PHR seedlings (see Table 1 for abbreviations and species traits). Species were nested by seed or seedling types. The effects of seed burial (surface and buried) and mulching (no-mulch, 5-cm and 10-cm of straw mulch) were tested. Column heights indicate means and error bars, SE. ANOVAs were performed for seed shape, seedling morpho-functional types and seed size, testing their interactions with the seed burial and mulching treatments, followed by Tukey tests. Different letters above bars indicate significant differences between treatments. 


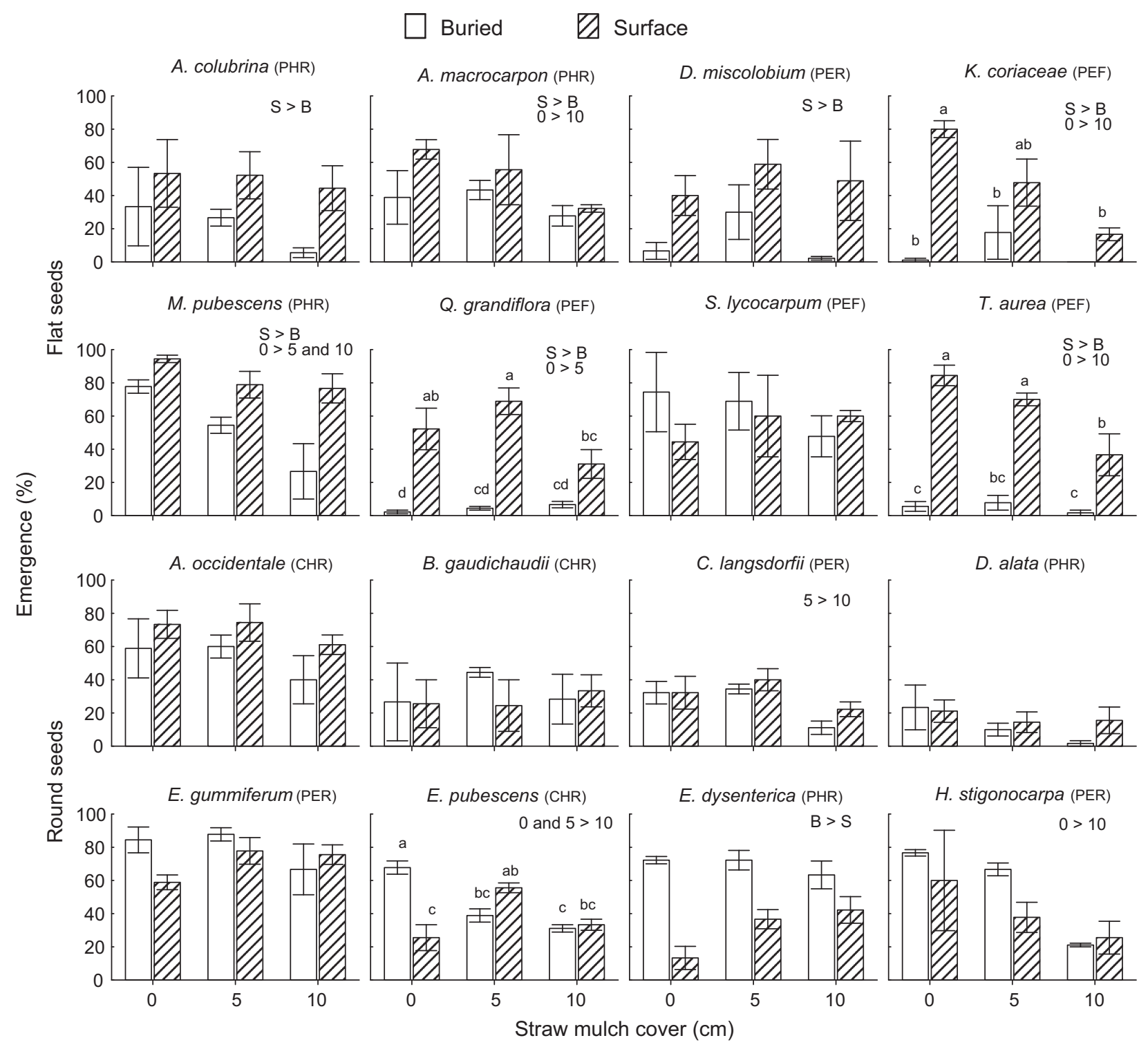

Fig. 2. Emergence (\%) of 16 Cerrado tree species, with different seed burial [surface (S) and buried (B)] and mulching [no-mulch $(0 \mathrm{~cm}), 5 \mathrm{~cm}$ and $10 \mathrm{~cm}$ of straw mulch] treatments. See Table 1 for the abbreviations of CHR, PER, PEF and PHR; seed sizes can be small (S), medium (M) or large (L). Columns show mean and error bars show SE. An ANOVA was performed for each species, followed by Tukey tests. Significant differences between main factors are indicated by the symbol > (indicating higher emergence), and interactions are represented by letters above bars, where different letters represent significant differences between treatments.

recalcitrant seeds and had higher emergence when seeds were buried, and Eriotheca pubescens, which benefited from some kind of cover, either seed burial with no mulch or surface seeding with $5 \mathrm{~cm}$ of mulch (Fig. 2, Appendix S4).

\section{Seedling size}

After 16 months, above-ground seedling size was low for all species. The tallest species, on average, was Hymenaea stigonocarpa $(19 \mathrm{~cm})$, and the species with the maximum mean diameter was Dipteryx alata (4.2 mm; Appendix S5).
Stem volume increased with mulching in five out of the 16 species, and one species grew better without mulch. Thus, mulching benefited a third of the studied species, with increases of $50-185 \%$ in seedling volume relative to no-mulch (Fig. 3, Appendix S6).

\section{Seedling survival}

Including all 16 species analysed, there were 2655 live seedlings, corresponding to $27 \%$ of all planted seeds (seeds converted to 16 -mo-old seedlings) and $73 \%$ of the 


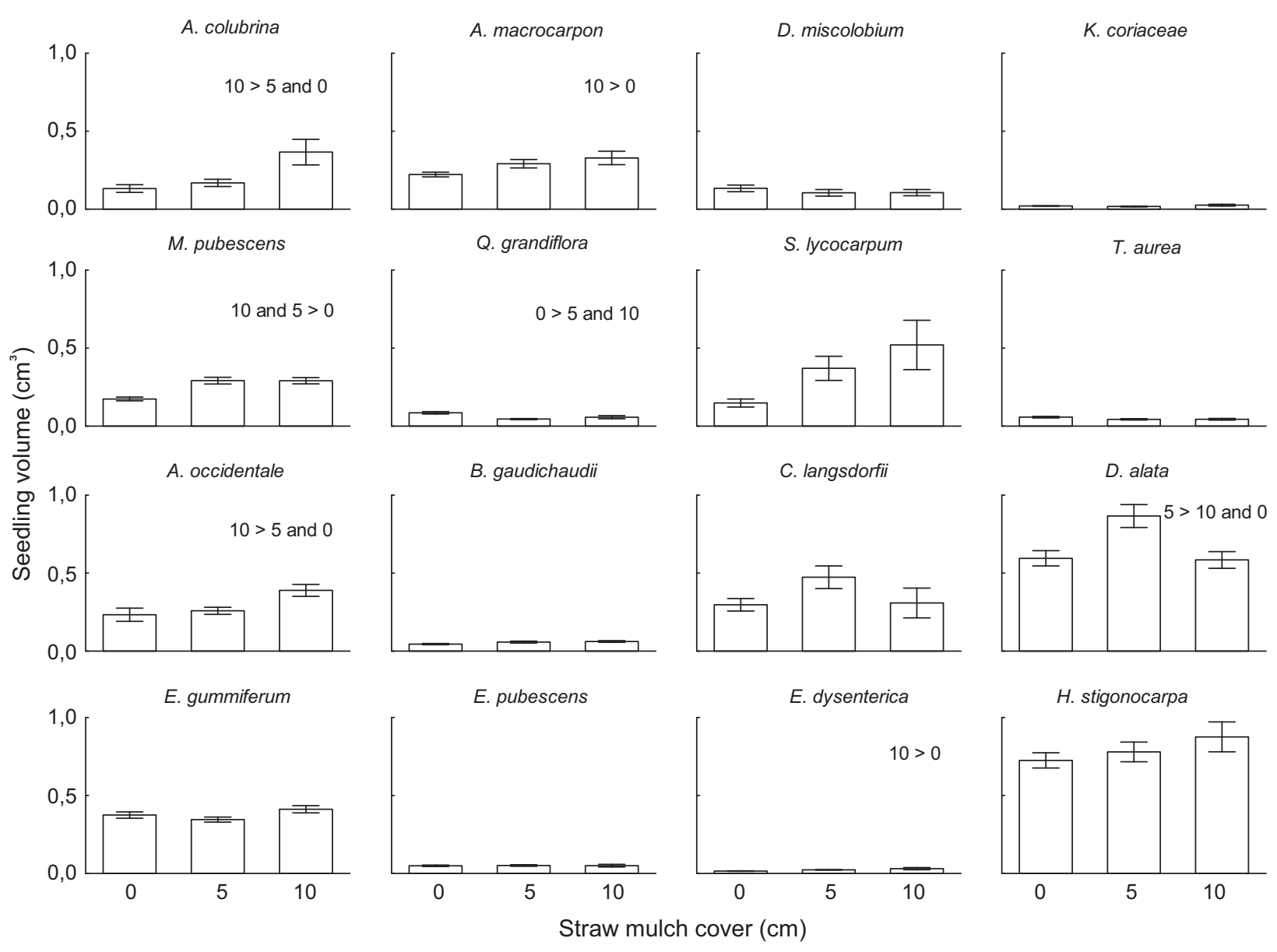

Fig. 3. Effects of mulching [no-mulch $(0 \mathrm{~cm}), 5 \mathrm{~cm}$ and $10 \mathrm{~cm}$ of straw mulch] on seedling size (volume $=$ height/3 $\times$ basal area) of 16 tree species, 16 months after sowing. Columns show means and error bars show SE. An ANOVA was performed for each species, followed by Tukey tests. Significant differences between main factors are shown by the symbol > (indicating higher emergence), and interactions are represented by letters above bars, where different letters represent significant differences between treatments.

emerged seedlings (survival). Eugenia dysenterica had the highest survival rate (99\%) and C. langsdorfii had the lowest $(9 \%)$. Seedling survival was not affected by mulching (Fig. 4; for statistical results see Appendix S7).

\section{Discussion}

In this study, overall germination was $43 \%$ and overall survival was $69 \%$, a success rate of $30 \%$ after 1 yr. Emergence was relatively high regardless of seed traits, even for traits known to result in low emergence rates, such as a small size (40\% emergence) and a flat shape (42\%). These figures suggest that direct seeding may be a highly efficient method for establishing trees in the field. We chose species with an assortment of seed and seedling traits that can be found in other ecosystems. However, since savannas are non-forest tropical ecosystems, these seeds are adapted to high temperature and variable humidity, increasing their potential to resist desiccation. These adaptations should therefore also result in higher germination and survival in open areas subject to restoration, compared to late successional species. The only recalcitrant species studied was E. dysenterica, which had higher germination rates in the buried or 10-cm mulch treatments.

Recent reviews concluded that direct seeding was only effective for species with seeds that are large $(>2 \mathrm{~g}$; Palma $\delta$ Laurance 2015; Ceccon et al. 2016), round and have low to medium water content (Tunjai \& Elliott 2012). Large seeds and the resulting seedlings are more resistant to desiccation and herbivory (Palma \& Laurance 2015) and less affected by microhabitat variation, such as soil and mulch cover (Doust et al. 2006). However, in the present study, the emergence of small seeds $(<0.1 \mathrm{~g})$ was not low, which was also observed by Doust et al. (2006). Also worth noting is that the soil here was prepared using a bed former, creating a fine, aerated, clod-free soil. This may 

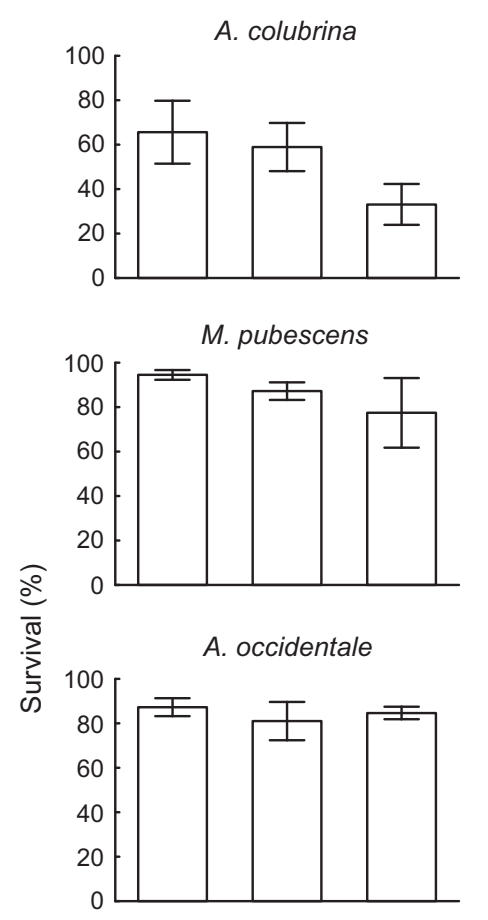

E. gummiferum

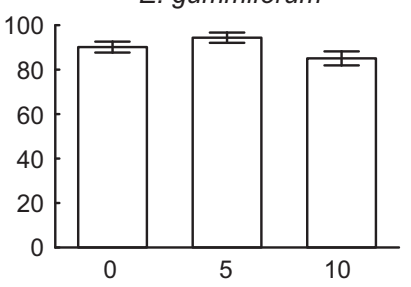

A. macrocarpon

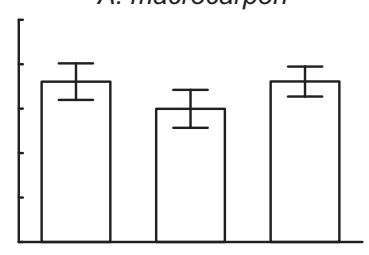

Q. grandiflora

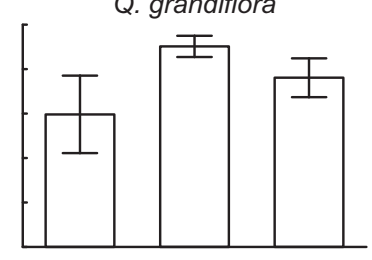

B. gaudichaudii

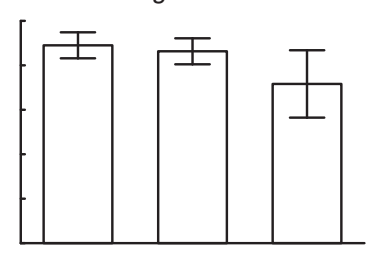

E. pubescens

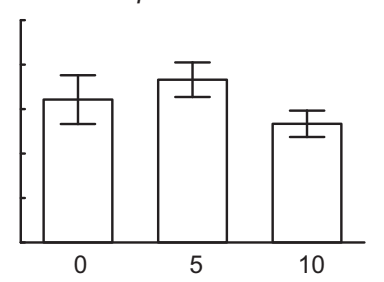

D. miscolobium

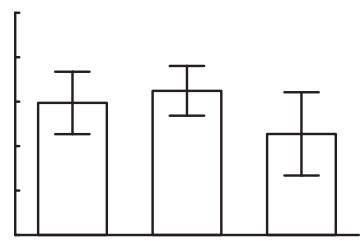

S. lycocarpum

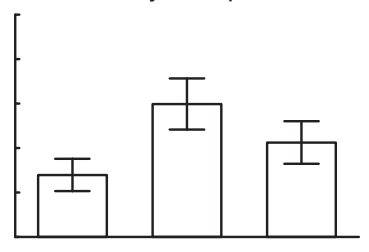

C. langsdorfii

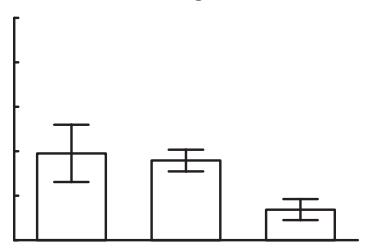

E. dysenterica

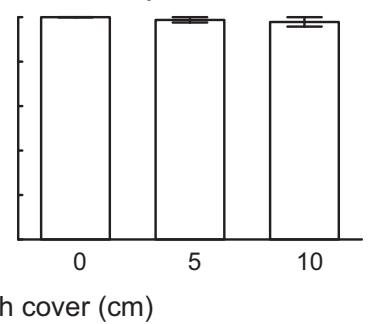

K. coriaceae

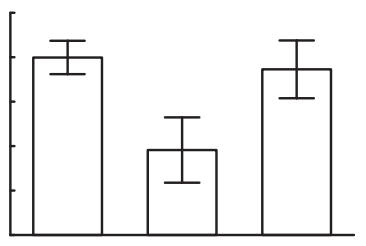

T. aurea

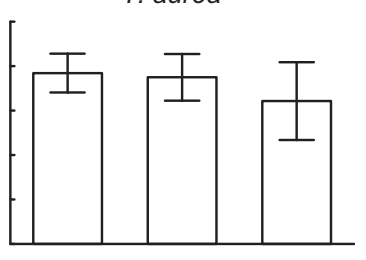

D. alata

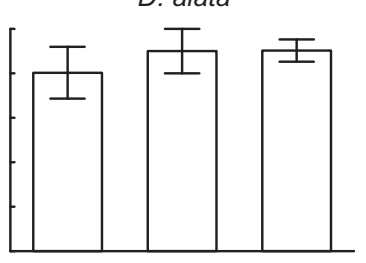

H. stigonocarpa

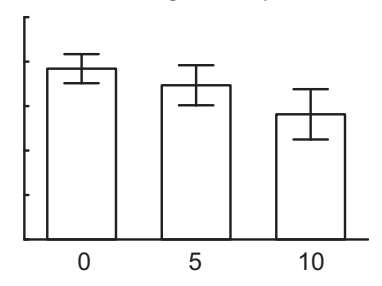

Fig. 4. Effects of mulching [no-mulch $(0 \mathrm{~cm}), 5-\mathrm{cm}$ and $10-\mathrm{cm}$ straw mulch] on the survival of 16 species, 16 months after seeding. Columns show means and bars indicate SE. An ANOVA was conducted for each species.

have increased germination rates of all species, particularly on the soil surface, compared to broadcasting seeds with little to no soil preparation.

A major challenge of using direct seeding for ecological restoration is to reintroduce species with different types of seeds and seedlings simultaneously. Management strategies must take into account all species to be planted at the same time, or be sufficiently versatile to provide benefits to all functional groups. Seedlings of round-seeded species, which have hypogeal cotyledons, emerged easily through the soil and mulch layers, while flat-seeded species, which have epigeal leaf-like cotyledons, had lower emergence when buried or covered with mulch. Therefore, these traits are important when considering seeding techniques. Covering seeds is always desirable to prevent desiccation and predation, since these are the most important factors restricting seedling emergence (Holl 1999; Garcia-Orth \&
Martinez-Ramos 2008; Sovu et al. 2010). The present study demonstrated that flat-seeded species should not be buried; instead, it is better to mulch, because the reduction in seedling emergence is less accentuated compared to uncovered seeds. Round-seeded species had similar seedling emergence rates at the surface and at $3-\mathrm{cm}$ depth, except for $E$. dysenterica, which has recalcitrant seeds and is more susceptible to desiccation in open areas (Andrade et al. 2003; Vieira \& Scariot 2006). Thus, in the case of recalcitrant seeds, it is advisable to bury the seeds to prevent desiccation (Woods \& Elliott 2004; Vieira \& Scariot 2006).

\section{Effects of mulching and exotic grass competition}

Mulching reduces temperature fluctuation and ground water evaporation, preserving water during dry periods 
(Haywood 1999; Gonzalez-Sosa et al. 2001; Mollard et al. 2014). Lower temperatures, coupled with higher soil moisture, favour microbial activity and steadier decomposition rates, adding nutrients to the soil (Athy et al. 2006). All these improvements in microsite conditions and resources increase seedling emergence, survival and growth (for an example in prairie, see Mollard et al. 2014; in dense shrubby heathland, Benigno et al. 2013; in forests in the Alps, Breton et al. 2016). In our study, not only did mulching affect soil moisture, it also prevented the emergence of an intentionally seeded invasive grass. The 10 -cm mulch treatment resulted in plots with no $U$. decumbens tussocks, while the no-mulch treatment yielded a thick cover of $U$. decumbens tussocks. Mulching inhibited invasive grasses without strongly reducing tree seedling emergence. However, despite the fact that after 1 yr the $5-\mathrm{cm}$ mulch had disappeared and the depth of the $10-\mathrm{cm}$ mulch had decreased to $1 \mathrm{~cm}, U$. decumbens had not emerged in these plots by the end of the experiment. Therefore, new mulch may be added annually, or as needed, to reduce the risk of invasion by grasses and ensure seedling development. It is important to note that applying mulch is simple when seeds are sown in rows or hollows, but this type of maintenance would be difficult with broadcast seeding. Compared to other methods for controlling invasive grasses at the beginning of restoration plantations, such as herbicides, manual clipping (Thaxton et al. 2012) and topsoil removal (Buisson et al. 2008), using mulch combined with direct seeding is convenient, provided grass straw can be harvested on site.

Invasive grasses are dominant in many parts of the globe undergoing restoration efforts (Williams \& Baruch 2000). The grass $U$. decumbens had high emergence rates in the absence of mulch, forming a closed canopy that filtered $53 \%$ of the light and reducing soil moisture by $50 \%$ in the middle of the dry season. The grass genus Urochloa is known for its high productivity in savanna ecosystems (Guenni et al. 2002) and noticeably reduces the survival and growth of tree seedlings. Pot experiments demonstrated that the biomass of a native Australian species, Alphitonia petrie, was 17 times higher in the absence of $U$. decumbens (Sun \& Dickinson 1996). Similarly, seven Cerrado tree species survived five times better and grew three times taller when Urochloa brizantha was completely removed with herbicide (glyphosate), compared to a clipping treatment and a no-weeding control (Pereira et al. 2013). These studies suggest that competition takes place below the ground, primarily for water and nutrients. In a third of the studied species, seedling growth was significantly better in the absence of grass $(10-\mathrm{cm}$ mulch treatment) than in the treatment invaded by $U$. decumbens. Larger differences should be observed in longer experiments and in below-ground growth.

\section{Implications for Brazilian savanna restoration}

In Cerrado, seedling emergence is a stronger constraint for tree establishment than early survival, and improving conditions for germination is a research priority (see also Silva et al. 2015). Specifically, research should focus on testing methods of soil preparation to improve germination conditions and to control exotic competitors. In observational studies at a Cerrado reserve, seedling survival was higher (Salazar et al. 2012a) than in other direct seeding studies (Ceccon et al. 2016), with low tree seedling density in the savanna explained instead by seed limitation and fire (Zida et al. 2007; Salazar et al. 2012b). Therefore, restoration methods that add seeds to a finely prepared soil and prevent fire are likely to succeed in establishing Neotropical savanna trees. Despite the relative success of direct seeding for the establishment of tree species with a variety of seed and seedling traits, the slow growth rate in the early years (see Hoffmann \& Franco 2003; Silva et al. 2015) is a major constraint for Cerrado restoration. In this study, the average seedling height at 16 months was $10.3 \mathrm{~cm}(N=2579$ stems). The initial period of slow growth requires efficient strategies to control unwanted species for an extended period. Therefore, different 'waiting' strategies may be used during restoration, depending on the restoration goals. For example, in taungya agroforestry systems, short-cycle crops are cultivated between rows of trees until the trees start to shade them (Menzies 1988). Alternatively, the soil may be planted with native herbaceous and shrub species, which represent $87 \%$ of Cerrado spermatophytes and are six times denser than trees. Although many issues should be considered for a comprehensive Cerrado restoration, this study shows that the interaction between seed traits and initial growth conditions must be taken into account to maximize the effectiveness of the early stages of the restoration process.

\section{Acknowledgements}

We are very grateful to Daniel R. Oliveira, Gustavo P.E. da Rocha, Dilmar M. T. Brandão and André G. Coutinho for assistance in establishing and monitoring the experiment. Dulce Alves da Silva followed the germination of the studied seeds in the laboratory. Professors Giselda Durigan and Fabian Borghetti provided helpful advice in an early version of this manuscript. Three anonymous reviewers provided deep and thoughtful comments. Beatriz Baker conducted a careful English review. R.R.P. Silva had CNPq grants (DTI-C). Funding was provided by CNPq (Edital MCT/CNPq/CT-Agro 561847/2010-0). DLMV conceived the research; RRPS performed the experiments and analysed the data; DLMV and RRPS led manuscript writing. 


\section{References}

Almeida, R.F., Fagg, C.W., de Oliveira, M.C., Munhoz, C.B.R., de Lima, A.S. \& de Oliveira, L.S.B. 2014. Floristic and structural changes in the Cerrado sensu stricto over 27 years (1985-2012) at Fazenda Água Limpa, Brasília, DF. [Mudanças florísticas e estruturais no Cerrado sensu stricto ao longo de 27 anos (1985-2012) na Fazenda Água Limpa, Brasília, DF]. Rodriguésia 65: 01-19.

Andrade, A.C.S., Cunha, R., Souza, A.F., Reis, R.B. \& Almeida, K.J. 2003. Physiological and morphological aspects of seed viability of a neotropical savannah tree, Eugenia dysenterica DC. Seed Science and Technology 31: 125-137.

Athy, E.R., Keiffer, C.H. \& Stevens, M.H. 2006. Effects of mulch on seedlings and soil on a closed landfill. Restoration Ecology 14: 233-241.

Baraloto, C. \& Forget, P.-M. 2007. Seed size, seedling morphology, and response to deep shade and damage in neotropical rain forest trees. American Journal of Botany 94: 901-911.

Benigno, S.M., Dixon, K.W. \& Stevens, J.C. 2013. Increasing soil water retention with native-sourced mulch improves seedling establishment in postmine Mediterranean sandy soils. Restoration Ecology 21: 617-626.

Ministério do Meio Ambiente, Brasil 2015. Mapeamento do Uso e Cobertura Vegetal do Cerrado: Projeto TerraClass Cerrado. MMA, Brasília, BR.

Breton, V., Crosaz, Y. \& Rey, F. 2016. Effects of wood chip amendments on the revegetation performance of plant species on eroded marly terrains in a Mediterranean mountainous climate (Southern Alps, France). Solid Earth 7: 599-610.

Bridgewater, S., Ratter, J.S.A. \& Ribeiro, J.F. 2004. Biogeographic patterns, $\beta$-diversity and dominance in the cerrado biome of Brazil. Biodiversity e Conservation 13: 2295-2317.

Buisson, E., Anderson, S., Holl, K.D., Corcket, E., Hayes, G.F., Peeters, A. \& Dutoit, T. 2008. Reintroduction of Nassella pulchra to California coastal grasslands: effects of topsoil removal, plant neighbour removal and grazing. Applied Vegetation Science 1 1: 195-204.

Camargo, J.L.C., Ferraz, I.D.K. \& Imakawa, A.M. 2002. Rehabilitation of degraded areas of central Amazonia using direct sowing of forest tree seeds. Restoration Ecology 10: 636-644.

Campos-Filho, E.M., Da Costa, J.N.M.N., De Sousa, O.L. \& Junqueira, R.G.P. 2013. Mechanized direct-seeding of native forests in Xingu, Central Brazil. Journal of Sustainable Forestry 32: 702-727.

Carr, D., Bonney, N., Huxtable, D. \& Bartle, J. 2009. Improving direct seeding for woody crops in temperate Australia: a review. Rural Industries Research and Development Corporation, Canberra, AU.

Ceccon, E., Gonzalez, E.J. \& Martorell, C. 2016. Is direct seeding a biologically viable strategy for restoring forest ecosystems? Evidence from a meta-analysis. Land Degradation $\theta$ Development 27: 511-520.
Cole, R.J., Holl, K.D., Keene, C.L. \& Zahawi, R.A. 2011. Direct seeding of late-successional trees to restore tropical montane forest. Forest Ecology and Management 261: 15901597.

Doust, S.J., Erskine, P.D. \& Lamb, D. 2006. Direct seeding to restore rainforest species: microsite effects on the early establishment and growth of rainforest tree seedlings on degraded land in the wet tropics of Australia. Forest Ecology and Management 234: 333-343.

Doust, S.J., Erskine, P.D. \& Lamb, D. 2008. Restoring rainforest species by direct seeding: tree seedling establishment and growth performance on degraded land in the wet tropics of Australia. Forest Ecology and Management 256: 1178-1188.

Felfili, J.M. \& Silva Júnior, M.C.d.. 1988. Distribuição dos diâmetros numa faixa de Cerrado na Fazenda Água Limpa (FAL), em Brasilia-DF [Stem diameter distribution in a "cerrado" area in the Água Limpa Farm, Brasilia, DF, Brazil]. Acta Botanica Brasilica 2: 85-105.

Fergus, I. 2004. A history of direct seeding. Victorian landcare and catchment management 31: 6-7.

Furley, P.A. 1999. The nature and diversity of neotropical savanna vegetation with particular reference to the Brazilian Cerrados. Global Ecology and Biogeography 8: 223-241.

Garcia-Orth, X. \& Martinez-Ramos, M. 2008. Seed dynamics of early and late successional tree species in tropical abandoned pastures: seed burial as a way of evading predation. Restoration Ecology 16: 435-443.

Gonzalez-Sosa, E., Braud, I., Thony, J.L., Vauclin, M. \& Calvet, J.C. 2001. Heat and water exchanges of fallow land covered with a plant-residue mulch layer: a modelling study using the three year MUREX data set. Journal of Hydrology 244: 119-136.

Guarino, E.d.S.G. \& Scariot, A. 2014. Direct seeding of dry forest tree species in abandoned pastures: effects of grass canopy and seed burial on germination. Ecological Research 29: 473482.

Guenni, O., Marin, D. \& Baruch, Z. 2002. Responses to drought of five Brachiaria species. I. Biomass production, leaf growth, root distribution, water use and forage quality. Plant and Soil 243: 229-241.

Haywood, J.D. 1999. Durability of selected mulches, their ability to control weeds, and influence growth of loblolly pine seedlings. New Forests 18: 263-276.

Hoffmann, W.A. 2000. Post-establishment seedling success in the Brazilian Cerrado: a comparison of savanna and forest species'. Biotropica 32: 62-69.

Hoffmann, W.A. \& Franco, A.C. 2003. Comparative growth analysis of tropical forest and savanna woody plants using phylogenetically independent contrasts. Journal of Ecology 91: 475-484.

Holl, K.D. 1999. Factors limiting tropical rain forest regeneration in abandoned pasture: seed rain, seed germination, microclimate, and soil. Biotropica 31: 229-242. 
Ibarra-Manriquez, G., Ramos, M.M. \& Oyama, K. 2001. Seedling functional types in a lowland rain forest in Mexico. American Journal of Botany 88: 1801-1812.

Jiménez-Alfaro, B., Silveira, F.A., Fidelis, A., Poschlod, P. \& Commander, L.E. 2016. Seed germination traits can contribute better to plant community ecology. Journal of Vegetation Science 27: 637-645.

Libano, A.M. \& Felfili, J.M. 2006. Mudanças temporais na composição florística e na diversidade de um Cerrado sensu stricto do Brasil Central em um período de 18 anos (19852003). Acta Botanica Brasilica 20: 927-936.

Lobo, G.A. 2012. Ensaios para a validação de metodologias para germinação de diásporos de espécies arbóreas do cerrado [Assays for validation of methodologies for germination of diaspores of cerrado tree species]. Dissertação de Mestrado em Biologia Vegetal. Universidade de Uberlândia, Uberlândia, MG, BR.

Martins, C.R., Hay, J.D.V., Walter, B.M.T., Proença, C.E.B. \& Vivaldi, L.J. 2011. Impacto da invasão e do manejo do capim-gordura (Melinis minutiflora) sobre a riqueza e biomassa da flora nativa do Cerrado sentido restrito. Brazilian Journal of Botany 34: 73-90.

Menzies, N. 1988. Three hundred years of taungya: a sustainable system of forestry in south China. Human Ecology 16: 361376.

Moles, A.T., Hodson, D.W. \& Webb, C.J. 2000. Seed size and shape and persistence in the soil in the New Zealand flora. Oikos 89: 541-545.

Mollard, F.P.O., Naeth, M.A. \& Cohen-Fernandez, A. 2014. Impacts of mulch on prairie seedling establishment: facilitative to inhibitory effects. Ecological Engineering 64: 377-384.

Montoro, G. R. 2008. Morfologia de plântulas de espécies lenhosas do cerrado [Seedling morphology of fourteen cerrado woody species]. Dissertação de Mestrado em Botânica. Universidade de Brasília, Brasília, DF, BR.

Moreira, A.G. 2000. Effects of fire protection on savanna structure in Central Brazil. Journal of Biogeography 27: 1021-1029.

Palma, A.C. \& Laurance, S.G.W. 2015. A review of the use of direct seeding and seedling plantings in restoration: what do we know and where should we go? Applied Vegetation Science 18: 561-568.

Pereira, S.R., Laura, V.A. \& Souza, A.L.T. 2013. Establishment of Fabaceae tree species in a tropical pasture: influence of seed size and weeding methods. Restoration Ecology 21: 67-74.

Ressel, K., Guilherme, F.A.G., Schiavini, I. \& Oliveira, P.E. 2004. Ecologia morfofuncional de plântulas de espécies arbóreas da Estação Ecológica do Panga, Uberlândia, Minas Gerais [Functional morphology and ecology of tree species seedlings of the Ecological Station of Panga, Uberlândia, Minas Gerais]. Brazilian Journal of Botany 27: 311-323.

Salazar, A., Goldstein, G., Franco, A.C. \& Miralles-Wilhelm, F. 2012a. Differential seedling establishment of woody plants along a tree density gradient in Neotropical savannas. Journal of Ecology 100: 141 1-1421.
Salazar, A., Goldstein, G., Franco, A.C. \& Miralles-Wilhelm, F. 2012 b. Seed limitation of woody plants in Neotropical savannas. Plant Ecology 213: 273-287.

Schneemann, B. \& McElhinny, C. 2012. Shrubby today but not tomorrow? Structure, composition and regeneration dynamics of direct seeded revegetation. Ecological Management and Restoration 13: 282-289.

Silva, R.R.P., Oliveira, D.R., da Rocha, G.P.E. \& Vieira, D.L.M. 2015. Direct seeding of Brazilian savanna trees: effects of plant cover and fertilization on seedling establishment and growth. Restoration Ecology 23: 393-401.

Sovu, P.S., Tigabu, M. \& Oden, P.C. 2010. Restoration of former grazing lands in the highlands of Laos using direct seeding of four native tree species. Mountain Research and Development 30: 232-243.

Sun, D. \& Dickinson, G.R. 1996. The competition effect of Brachiaria decumbens on the early growth of direct-seeded trees of Alphitonia petriei in tropical north Australia. Biotropica 28: 272-276.

Thaxton, J.M., Cordell, S., Cabin, R.J. \& Sandquist, D.R. 2012. Non-native grass removal and shade increase soil moisture and seedling performance during Hawaiian dry forest restoration. Restoration Ecology 20: 475-482.

Tunjai, P. \& Elliott, S. 2012. Effects of seed traits on the success of direct seeding for restoring southern Thailand's lowland evergreen forest ecosystem. New Forests 43: 319-333.

Vieira, D.L.M. \& Scariot, A. 2006. Effects of logging, liana tangles and pasture on seed fate of dry forest tree species in Central Brazil. Forest Ecology and Management 230: 197205.

Williams, D.G. \& Baruch, Z. 2000. African grass invasion in the americas: ecosystem consequences and the role of ecophysiology. Biological Invasions 2: 123-140.

Woods, K. \& Elliott, S. 2004. Direct seeding for forest restoration on abandoned agricultural land in northern Thailand. Journal of Tropical Forest Science 16: 248-259.

Zida, D., Sawadogo, L., Tigabu, M., Tiveau, D. \& Oden, P.C. 2007. Dynamics of sapling population in savanna woodlands of Burkina Faso subjected to grazing, early fire and selective tree cutting for a decade. Forest Ecology and Management 243: $102-115$.

\section{Supporting Information}

Additional Supporting Information may be found in the online version of this article:

Appendix S1. Experimental design scheme.

Appendix S2. Soil moisture, irradiance and density of Urochloa decumbens tussocks in plots with no-mulch $(0 \mathrm{~cm}), 5-\mathrm{cm}$ and $10-\mathrm{cm}$ straw mulch.

Appendix S3. ANOVAs for the effects of seed burial depth and mulching on seedling emergence, depending on seed shape, seed size and seedling morpho-functional type. 
Appendix S4. ANOVAs for the effects of seed burial depth and mulching on seedling emergence and establishment.

Appendix S5. Seedling height and diameter 16 months after seeding.
Appendix S6. ANOVAs for the effects of mulching on the seedling volume 16 months after seeding.

Appendix S7. ANOVAs for the effects of mulching on the seedling survival 16 months after seeding. 